\title{
Research Article \\ SEROPREVALENCE OF HEPATITIS C VIRUS INFECTION AMONG PREGNANT WOMEN ATTENDING A TEACHING HOSPITAL OF ATARIA, NORTH INDIA
}

\author{
KHATOON RAZIA ${ }^{1}$ AND JAHAN NOOR ${ }^{*}$ \\ 1Department of Microbiology, Hind Institute of Medical Sciences, Mau, Ataria, Sitapur, 261303, India \\ 2Department of Microbiology, Integral Institute of Medical Sciences \& Research, Integral University, Lucknow, 226026, India \\ *Corresponding Author: Email-drnoorj@rediffmail.com
}

Received: January 12, 2017; Revised: January 20, 2018; Accepted: January 21, 2018; Published: January 30, 2018

\begin{abstract}
Hepatitis $\mathrm{C}$ virus $(\mathrm{HCV})$ is a major cause of viral hepatitis and hepatic dysfunction during pregnancy throughout the world. HCV infection leads to complications like premature labour, preterm delivery and maternal mortality. Virus may be transmitted vertically to neonates leading to neonatal hepatitis. The present study was done to estimate the seroprevalence of Hepatitis $C$ virus infection among pregnant women. Total of 2067 pregnant women were enrolled in the study whose serum sample was tested for anti-Hepatitis $C$ virus antibody using rapid test and those found reactive were confirmed using enzyme linked immunosorbent assay (ELISA). Out of 2067 pregnant women tested, 24 were found to be reactive by both rapid test and ELISA, hence the seroprevalen ce was $1.2 \%$. Maximum seropositivity was seen in pregnant women of age group 26-30 years. Seropositivity was more among working pregnant women, belonging to rural areas and those who were poor and belonged to lower socio-economic class. All these findings were statistically significant. Amongst the risk factors studied, most of the seropositives gave history of previous surgery followed by history of dilatation and curettage. To conclude, it is strongly recommended that all pregnant women should be screened for anti-Hepatitis $C$ virus antibodies in order to know their infection status and thus prevent adverse outcome of pregnancy and its vertical transmission to their neonates.
\end{abstract}

Keywords- Seroprevalence, Hepatitis C infection, Risk factors, Pregnant women.

Citation: Khatoon Razia and Jahan Noor (2018) Seroprevalence of Hepatitis C virus infection among pregnant women attending a teaching hospital of Ataria, North India. International Journal of Microbiology Research, ISSN: 0975-5276 \& E-ISSN: 0975-9174, Volume 10, Issue 1, 1001-1004. DOI: http://dx.doi.org/10.9735/0975-5276.10.1.1001-1004

Copyright: Copyright@2018 Khatoon Razia and Jahan Noor. This is an open-access article distributed under the terms of the Creative Commons Attribution License, which permits unrestricted use, distribution and reproduction in any medium, provided the original author and source are credited.

Academic Editor / Reviewer: Dr Sudipta Chakraborti

\section{Introduction}

Hepatitis $\mathrm{C}$ virus (HCV) infection is one of the major health problems throughout the world. HCV is a blood borne pathogen that attacks liver and causes acute and chronic hepatitis, liver cirrhosis and hepatocellular carcinoma [1]. HCV infection is asymptomatic in a large proportion of cases $(65-75 \%)$ and revealed only accidentally by abnormal liver function tests and /or anti-HCV antibody positivity [2]. According to World Health Organisation (WHO), about 170 million people are chronically infected with HCV and each year around 4 million people are newly infected with it [1]. The prevalence of HCV infection varies from country to country with highest seroprevalence $(5.3 \%)$ reported in Africa as compared to low prevalence of $1.7 \%$ and $1.03 \%$ seen in North America and Europe respectively [35]. Its prevalence in India is about $1-2 \%$ [6]. HCV is transmitted through infected blood and blood products and also transmitted vertically to infants of infected mothers. Anti-HCV antibody screening of blood products introduced during the early 1990s has minimized this mode of HCV acquisition, leaving vertical transmission from infected mothers as the predominant mode of infection in children. Approximately 7-8 percent of hepatitis $C$ virus positive women transmit the virus to their offsprings [7]. Complications of HCV infection during pregnancy include premature contractions, placental separation, preterm delivery, vaginal bleeding, gestational diabetes mellitus and maternal mortality [8-10]. Neonatal hepatitis can lead to chronic virus carriage, which in turn may lead to liver cirrhosis and hepatocellular carcinoma in young adults [11,12].

HCV infections are spreading rapidly in the developing countries including India. Therefore, the current study was aimed at estimating the seroprevalence and the possible risk factors of $\mathrm{HCV}$ among pregnant women attending antenatal clinic
(ANC) in a teaching hospital at Ataria, North India, so that proper and timely treatment could be initiated thereby preventing mother to child transmission of this virus.

\section{Materials and Methods}

A hospital based cross-sectional study was done in the department of Microbiology, over a period of 1 year from August 2015 to July 2016 among pregnant women attending antenatal clinic of Hind Institute of Medical Sciences, Mau, Ataria, Sitapur, Uttar Pradesh, India, to determine the seroprevalence of hepatitis $C$ virus infection and its association with various risk factors among these pregnant women. The study was approved by Institutional Ethical Committee before commencing the study. A pre-designed questionnaire was used to collect the information regarding the demography, socio-economic status and risk factors for hepatitis $\mathrm{C}$ infection. To measure the socio-economic status of participants the criteria applied was Kuppuswamy socio economic status scale which includes education, occupation and family income per month [13]. An informed consent was taken from all pregnant women.

Inclusion criteria: All pregnant women of reproductive age group (15-45 years) who attended antenatal clinic and got admitted in labour room for delivery and were advised to undergo testing for anti-HCV antibody either as part of routine antenatal screening or pre-operative screening (caeserian section) were included in the study.

Exclusion criteria: Pregnant women who refused to give consent or who had 
liver diseases due to other causes were excluded from the study.

\section{Study subjects}

A total of 2067 healthy (asymptomatic) pregnant women whose blood samples were sent to Microbiology laboratory for testing anti-HCV antibodies were included in the present study.

\section{Methods}

$5 \mathrm{ml}$ of venous blood from each pregnant woman was received in a well labeled plain vacutainer tube. The blood was allowed to clot followed by centrifugation of the tube at $3000 \mathrm{rpm}$ for $15 \mathrm{~min}$ to separate serum. A rapid qualitative in vitro diagnostic HCV TRI-DOT test (J. Mitra \& Company Private Limited, India) was used to screen the sera [Fig-1]. Those found reactive were confirmed by using $3^{\text {rd }}$ generation HCV Microlisa an enzyme linked immunosorbent assay (ELISA) method (J. Mitra \& Company Private Limited, India). The HCV Microlisa is based on detection of host generated anti-HCV antibodies to viral proteins (Core E1, E2 and Non-Structural NS3, NS4 and NS5 antigens) coated into the microwells. The test was performed according to manufacturer's instruction. $100 \mu$ negative control, $100 \mu$ l positive control, $100 \mu$ l sample diluent and $10 \mu \mathrm{l}$ samples were added in the respective wells. The plate was then covered and incubated in an incubator at $37^{\circ} \mathrm{C} \pm 2^{\circ} \mathrm{C}$ for 30 minutes followed by washing with working wash solution. Then $100 \mu$ l working conjugate was added in each well. The plate was again covered and incubated in an incubator at $37^{\circ} \mathrm{C} \pm 2^{\circ} \mathrm{C}$ for 30 minutes. The plate was then washed with working wash solution followed by the addition of 100 $\mu \mathrm{l}$ working substrate solution in all the wells. The plate was then covered and incubated at room temperature $\left(20-30^{\circ} \mathrm{C}\right)$ for 30 minutes in dark. Finally, $100 \mu \mathrm{l}$ stop solution was added to each well and the absorbance was read at $450 \mathrm{~nm}$ in an ELISA reader. The Cut-off value was calculated by multiplying 0.23 with the mean absorbance of Positive control.

\section{Statistical analysis}

The SPSS Data Editor Software version 20 was used for analysis of the data. Chisquare test was performed and $p$ value $\leq 0.05$ were considered statistically significant.

\section{Results}

Total of 2067 pregnant women included in the study were screened for presence of anti-HCV antibodies. The mean age of pregnant females was $25.6( \pm 4.5)$ years ranging from 18 to 43 years. Of these 24 pregnant women were found to be reactive by both HCV TRI-DOT test as well as by HCV Microlisa (ELISA), giving the seroprevalence of anti-HCV antibodies to be 1.2\% [Table-1]. The distribution of pregnant women according to their age and anti-HCV seropositivity is shown in [Table-2]. This finding was found to be statistically significant $(p=0.020)$. The socio-demographic profiles of pregnant women included in our study and their relation to anti-HCV antibody reactivity is shown in [Table-3-5]. As shown in Table 3 , majority $(66.7 \%)$ of seropositives were illiterate, followed by those who had education upto primary school $(29.2 \%)$. This finding was found to be statistically significant $(p=0.022)$. [Table-4] shows that majority of seropositive pregnant women were unskilled workers (62.5\%), followed by semi-skilled workers (20.8\%). This finding was also found to be statistically significant $(p=0.005)$. [Table-5] shows that $79.2 \%$ seropositive pregnant women belonged to rural areas as compared to those from urban areas $(20.8 \%)$ and majority of seropositives were poor and belonged to lower socio-economic class (58.3\%), followed by those who belonged to middle class (37.5\%).

These differences were found to be statistically significant $(p=0.040 \& p=0.036$ respectively). [Table-6] shows the distribution of various risk factors for hepatitis $C$ infection among seropositive pregnant women. Of the total reactive pregnant women, $14(58.3 \%)$ showed presence of risk factors, whereas, $10(41.7 \%)$ women did not have any of the risk factors inquired in our study. Amongst the reactive pregnant women the most frequent risk factors for hepatitis $\mathrm{C}$ infection were found to be history of previous surgery $(42.9 \%)$, followed by history of dilatation \& curettage $(21.4 \%)$ and least frequent was history of previous blood transfusion $(7.1 \%)$.

Table-1 Distribution of pregnant women according to their anti-HCV antibody
status (N = 2067).
\begin{tabular}{|l|c|c|}
\hline Anti-HCV antibody test & Number of pregnant women & Percentage \\
\hline Reactive & 24 & $1.2 \%$ \\
\hline Non-Reactive & 2043 & $98.8 \%$ \\
\hline Total & 2067 & $100 \%$ \\
\hline
\end{tabular}

Table-2 Distribution of pregnant women according to age and their relation with anti-HCV antibody test reactivity $(N=2067)$.

\begin{tabular}{|c|c|c|c|c|}
\hline \multirow[b]{2}{*}{ Age group } & \multicolumn{3}{|c|}{ Anti-HCV antibody test } & \multirow{2}{*}{$\begin{array}{c}\text { Chi-Square } \\
\left(x^{2}\right) \text { \& } \\
\text { *p value }^{\text {p }}\end{array}$} \\
\hline & $\begin{array}{l}\text { Reactive } \\
\mathrm{N}(\%)\end{array}$ & $\begin{array}{c}\text { Non-Reactive } \\
\mathrm{N}(\%)\end{array}$ & $\begin{array}{l}\text { Total } \\
\mathrm{N}(\%)\end{array}$ & \\
\hline $15-20$ years & $2(8.3 \%)$ & $357(17.5 \%)$ & $359(17.4 \%)$ & \multirow{7}{*}{$\begin{aligned} X^{2} & =13.450 \\
p & =0.020\end{aligned}$} \\
\hline $21-25$ years & $6(25.0 \%)$ & $768(37.6 \%)$ & $774(37.4 \%)$ & \\
\hline $26-30$ years & $15(62.5 \%)$ & $590(28.9 \%)$ & $605(29.3 \%)$ & \\
\hline $31-35$ years & $1(4.2 \%)$ & $288(14.1 \%)$ & $289(14.0 \%)$ & \\
\hline $36-40$ years & $0(0.0 \%)$ & $34(1.7 \%)$ & $34(1.6 \%)$ & \\
\hline $41-45$ years & $0(0.0 \%)$ & $6(0.3 \%)$ & $6(0.3 \%)$ & \\
\hline Total & $24(100 \%)$ & $2043(100 \%)$ & $2067(100 \%)$ & \\
\hline & & $\begin{array}{l}\mathrm{d} \text { as statisticall } \\
\text { pregnant wom }\end{array}$ & $x_{1}=1$ & \\
\hline
\end{tabular}

$\overline{\text { Table-3 Educational status of pregnant women and their relation with anti-HCV }}$ antibody test reactivity $(N=2067)$.

\begin{tabular}{|c|c|c|c|c|}
\hline \multirow[b]{2}{*}{$\begin{array}{l}\text { Educational } \\
\text { status }\end{array}$} & \multicolumn{3}{|c|}{ Anti-HCV antibody test } & \multirow{2}{*}{$\begin{array}{l}\text { Chi-Square } \\
\left(x^{2}\right) \text { \& } \\
\text { "p value }\end{array}$} \\
\hline & $\begin{array}{l}\text { Reactive } \\
\mathrm{N}(\%)\end{array}$ & $\begin{array}{l}\text { Non-Reactive } \\
\mathrm{N}(\%)\end{array}$ & $\begin{array}{l}\text { Total } \\
\mathrm{N}(\%) \\
\end{array}$ & \\
\hline Illiterate & $16(66.7 \%)$ & $830(40.6 \%)$ & $846(40.9 \%)$ & \multirow{5}{*}{$\begin{aligned} X^{2} & =9.605 \\
p & =0.022\end{aligned}$} \\
\hline Primary School & $7(29.2 \%)$ & $576(28.2 \%)$ & $583(28.2 \%)$ & \\
\hline $\begin{array}{l}\text { Secondary } \\
\text { School }\end{array}$ & $1(4.2 \%)$ & $444(21.7 \%)$ & $445(21.5 \%)$ & \\
\hline $\begin{array}{l}\text { Graduate \& } \\
\text { above }\end{array}$ & $0(0.0 \%)$ & $193(9.4 \%)$ & $193(9.3 \%)$ & \\
\hline Total & $24(100 \%)$ & $2043(100 \%)$ & $2067(100 \%)$ & \\
\hline \multicolumn{5}{|c|}{$\begin{array}{c}{ }^{*} p<0.05 \text { was considered as statistically significant. } N=\text { Number of pregnant } \\
\text { women. }\end{array}$} \\
\hline
\end{tabular}

Table-4 Occupational profiles of pregnant women and their relation with anti-HCV antibody test reactivity $(N=2067)$.

\begin{tabular}{|c|c|c|c|c|}
\hline \multirow[b]{2}{*}{ Occupational status } & \multicolumn{3}{|c|}{ Anti-HCV antibody test } & \multirow{2}{*}{$\begin{array}{c}\text { Chi-Square } \\
\left(x^{2}\right) \text { \& } \\
{ }^{*} p \text { value }\end{array}$} \\
\hline & $\begin{array}{l}\text { Reactive } \\
\mathrm{N}(\%)\end{array}$ & $\begin{array}{c}\text { Non-Reactive } \\
\mathrm{N}(\%)\end{array}$ & $\begin{array}{l}\text { Total } \\
\mathrm{N}(\%)\end{array}$ & \\
\hline Housewife & $4(16.7 \%)$ & $935(45.8 \%)$ & $939(45.4 \%)$ & \multirow{5}{*}{$\begin{aligned} x^{2} & =12.666 \\
p & =0.005\end{aligned}$} \\
\hline Semi Skilled workers & $5(20.8 \%)$ & $146(7.1 \%)$ & $151(7.3 \%)$ & \\
\hline Unskilled workers & $15(62.5 \%)$ & $917(44.9 \%)$ & $932(45.1 \%)$ & \\
\hline Professionals & $0(0.0 \%)$ & $45(2.2 \%)$ & $45(2.2 \%)$ & \\
\hline Total & $24(100 \%)$ & $2043(100 \%)$ & $2067(100 \%)$ & \\
\hline & & $\begin{array}{l}\text { stically signific } \\
\text { women. }\end{array}$ & & \\
\hline
\end{tabular}

Table-5 Residence and socio-economic status of pregnant women and their relation with anti-HCV antibody test reactivity $(N=2067)$.

\begin{tabular}{|c|c|c|c|c|c|}
\hline \multirow{2}{*}{\multicolumn{2}{|c|}{ Characteristics }} & \multicolumn{3}{|c|}{ Anti-HCV antibody test } & \multirow[b]{2}{*}{$\begin{array}{l}\text { Chi-Square } \\
\quad\left(x^{2}\right) \text { \& } \\
\text { "p value }\end{array}$} \\
\hline & & $\begin{array}{l}\text { Reactive } \\
N=24 \\
(100 \%)\end{array}$ & $\begin{array}{c}\begin{array}{c}\text { Non-Reactive } \\
N=2043 \\
(100 \%)\end{array}\end{array}$ & $\begin{array}{c}\text { Total } \\
N=2067 \\
(100 \%) \\
\end{array}$ & \\
\hline \multirow[t]{2}{*}{ Residence } & Rural & $\begin{array}{c}19 \\
(79.2 \%)\end{array}$ & $1192(58.3 \%)$ & $\begin{array}{c}1211 \\
(58.6 \%)\end{array}$ & \multirow{2}{*}{$\begin{aligned} X^{2} & =4.238 \\
p & =0.040\end{aligned}$} \\
\hline & Urban & $5(20.8 \%)$ & $851(41.7 \%)$ & $856(41.4 \%)$ & \\
\hline \multirow{3}{*}{$\begin{array}{l}\text { Socio- } \\
\text { economic } \\
\text { status }\end{array}$} & $\begin{array}{l}\text { Upper } \\
\text { Class }\end{array}$ & $1(4.2 \%)$ & $87(4.3 \%)$ & $88(4.3 \%)$ & \multirow{3}{*}{$\begin{aligned} X^{2} & =6.674 \\
p & =0.036\end{aligned}$} \\
\hline & $\begin{array}{l}\text { Middle } \\
\text { Class }\end{array}$ & $9(37.5 \%)$ & $355(17.4 \%)$ & $364(17.6 \%)$ & \\
\hline & $\begin{array}{l}\text { Lower } \\
\text { Class }\end{array}$ & $\begin{array}{c}14 \\
(58.3 \%) \\
\end{array}$ & $1601(78.4 \%)$ & $\begin{array}{c}1615 \\
(78.1 \%) \\
\end{array}$ & \\
\hline \multicolumn{6}{|c|}{$\begin{array}{c}{ }^{*} p<0.05 \text { was considered as statistically significant. } N=\text { Number of pregnant } \\
\text { women. }\end{array}$} \\
\hline
\end{tabular}




\section{Discussion}

Viral hepatitis is the commonest cause of hepatic dysfunction in pregnancy throughout the world [14]. In our study, the seroprevalence of HCV among pregnant women was found to be $1.2 \%$. This is similar to various previous done studies which reported the seroprevalence of $\mathrm{HCV}$ among antenatal population to vary from $1-5 \%[2,15-18]$.

Table-6 Distribution of various risk factors of Hepatitis C virus infection among anti-HCV antibodies reactive pregnant women under study.

\begin{tabular}{|l|c|c|}
\hline \multicolumn{1}{|c|}{ Risk Factors } & $\begin{array}{c}\text { Anti-HCV antibodies } \\
\text { reactive pregnant women } \\
\text { with risk factors }(\mathrm{N}=14)\end{array}$ & Percentage \\
\hline Previous surgery & 06 & $42.9 \%$ \\
\hline History of dilatation \& curettage & 03 & $21.4 \%$ \\
\hline Previous abortion & 02 & $14.3 \%$ \\
\hline Presence of body piercing \& tattooing & 02 & $14.3 \%$ \\
\hline Previous blood transfusion & 01 & $7.1 \%$ \\
\hline \multicolumn{2}{|c|}{$\mathrm{N}=$ Number of pregnant women. } \\
\hline
\end{tabular}

The highest prevalence of infection occurs among individuals of reproductive age [19]. Age is a known risk factor for HCV infection. Seropositivity has been reported to be increased until the age 40 and then declines over time [20]. This can be explained by the greater probability of exposure of these young women to risk factors. In our study, highest seropositivity was found in pregnant women belonging to age group $26-30$ years $(62.5 \%)$, and as the age advanced seropositivity was found to decrease to $4.2 \%$ among women belonging to age group 31-35 years. Similarly, a study reported highest seropositivity among pregnant women belonging to $21-25$ years $(51.2 \%)$, followed by $26-30$ years (27.4\%) [2]. Another study reported highest HCV antibodies positivity among 2130 years $(70.6 \%)$ age group of pregnant women [21].

In our study, majority of HCV seropositive pregnant women were illiterate followed by those who had education up to primary school. This is in accordance with the results of another study which reported high frequency of HCV seropositivity among less educated women [2]. The present study depicted that majority of seropositives were unskilled workers by profession, followed by semi-skilled workers and housewives. In contrast to our finding, another study reported majority of seropositivity among housewives followed by daily workers [1].

Our study found that majority of seropositive pregnant women belonged to rural areas $(79.2 \%)$ as compared to those from urban areas $(20.8 \%)$. This is in agreement with another study which also reported that majority of seropositives belonged to rural areas as compared to those from urban areas [1]. This could be due to prevalence of poverty among rural population along with lack of knowledge about the causative agent, its modes of transmission and precautions [22].

The present study depicted that majority of seropositivity was seen in women belonging to lower socio-economic class, followed by those belonging to middle class. This is in agreement to another study which also reported highest frequency of seropositives belonging to lower class $(76.47 \%)$, followed by middle class $(14.70 \%)[22]$.

In the present study, $41.7 \%$ reactive pregnant women did not have any of the risk factors inquired in our study. This is in accordance with another study which showed that out of 84 anti-HCV positive women, 52 (61.9\%) did not have any identifiable risk factors [2]. Another study also reported presence of risk factors among $64(62.1 \%)$ out of 103 reactive pregnant women [14]. Our study showed that amongst various risk factors for $\mathrm{HCV}$, highest frequency was found to be history of previous surgery, followed by history of dilatation and curettage. Another study reported history of previous delivery and abortion as highest risk factor followed by history of dilatation and curettage and tattooing [14]. Another study also showed high frequency of seropositivity among pregnant women with history of obstetrics and gynaecology surgeries, followed by nose, ear piercing and tattooing [22]. The reason for such high frequency of these risk factors is based on previous reports findings which state that in resource poor countries the risk of iatrogenic HCV infection is high [23]. Also, in rural areas, most of the surgeries and deliveries are performed by untrained dais under unhygienic conditions. In our study history of blood transfusion was found to be least frequently associated with
HCV infection. The reason could be meticulous screening of blood and blood products for anti-HCV antibodies prior to transfusion.

The present study has limitations that due to resource constraints we were not able to detect HCV-RNA amongst all the anti-HCV antibody positive pregnant women, as the prevalence of HCV-RNA is important for mother to child transmission.

\section{Conclusion}

In developing countries because of poverty and lack of facilities, women have poor access to the hospitals. Therefore, it is recommended that stringent screening for anti-HCV antibodies should be done in all pregnant women during antenatal visits as this might be their only interaction to a health care facility, so that one can find out all those who are infected with hepatitis $C$ virus and therefore initiate the treatment at the earliest and prevent the disease transmission from mother to their newborns.

\section{Application of Research}

We detected 24 reactive pregnant women who were otherwise asymptomatic and thus could shave transferred the infection to their newborns.

Acknowledgement: Authors are thankful to Department of Microbiology, Hind Institute of Medical Sciences, Mau, Ataria, Sitapur, 261303 and Integral Institute of Medical Sciences \& Research, Integral University, Lucknow-226026, India

Author's Contributions: Both authors have equally contributed.

\author{
Abbreviations: \\ HCV - Hepatitis C virus \\ ELISA - Enzyme linked immunosorbent assay \\ WHO - World Health Organization \\ ANC - Antenatal Clinic \\ RNA - Ribonucleic Acid
}

Conflict of Interest: None declared.

Ethical Approval: Approved by Institutional Ethics Committee, Hind Institute of Medical Sciences, Mau, Ataria, Sitapur-261303, India

\section{References}

[1] Pyadala N., Maity S.N., Kothapalli J., Goud A.K., Borugadda R., Mallepaddi P.C. and Polavarapu R. (2016) Int J Res Dev Pharm Life Sciences, 5 , 2251-4.

[2] Kumar A., Sharma K.A., Gupta R.K., Kar P. and Chakravarti A. (2007) Indian J Med Res, 126, 211-5.

[3] Karoney M.J. and Siika A.M. (2013) The Pan Afri Med J, 14, 44.

[4] Global surveillance and control of hepatitis C (1999) J Viral Hepat, 6, 35-47.

[5] Shepard C.W., Finelli L. and Alter M.J. (2005) Lancet Infect Dis, 5, 558-67.

[6] Chowdhury A., Santra A., Chaudari S., Dhali G.k., Maity S.G., Naik T.N., Bhattacharya S.K. and Mazumder D.N. (2003) Hepatology, 37, 802-9.

[7] ACOG Educational Bulletin. Viral hepatitis in pregnancy. Number 248, July (1998) Int J Gynaecol Obstet, 63,195-202.

[8] Chen S.L. and Morgan T.R. (2006) Int J Med Sci, 3, 47.

[9] Reddick K., Jhaveri R., Gandhi M., James A. and Swamy G. (2011) J Viral Hepatitis, 18, e394-e398.

[10] Safir A., Levy A., Sikuler E. and Sheiner E. (2010) Liver International, 30 , 765-70.

[11] Sookoian S. (2006) Ann Hepatol, 5, 231-6.

[12] Wright T.L. (2006) Am J Gastroenterol, 101, 1-6.

[13] Kumar N., Gupta N. and Kishore J. (2012) Indian J Pub Health, 56, 103-4.

[14] Ishaq T., Khattaq M.I., Amin S. and Haq N.U. (2011) Frequency and risk factors for hepatitis C among pregnant women. Gomal J Med Sci; 9: 166-9.

[15] Garner J.J., Gaughwin M., Dodding J. and Willson K. (1997) Med J Aust, 166, 470-2. 
[16] Silverman N.S., Jenkin B.K., Wu C., Mcgilennen P. and Knee G. (1993) Am J Obstet Gynecol, 169, 583-7.

[17] Bohman V.R., Stettler W., Little B.B., Wendel G.D., Sutor L.J. and Cunningham F.G. (1992) Obstet Gynecol., 80, 609-13.

[18] Marranconi F., Fabris P., Stecca C., Zampieri L., Bettini M.C., Di Fabrizio N. and de Lalla F. (1994) Infection, 22, 333-7.

[19] Wasley A.D. and Alter M.J. (2000) Semin Liver Dis., 20, 1-16.

[20] Stevens C.E., Taylor P.E., Pindyck J., Choo Q.L., Bradley D.W., Kuo G. and Houghton M. (1990) JAMA, 263, 49-53.

[21] Dayal S., Singh A., Chaturvedi V., Pathak A., Gupta V. and Jaiswal S. (2015) Ann Clin Chem Lab Med, 1, 3-7.

[22] Ahmad I., Khan S.B., Rahman H.U., Khan M.H. and Anwar S. (2006) Gomal J Med Sci, 4, 61-4.

[23] Hutin Y., Hauri A. and Armstrong G. (2003) BMJ, 327, 1073-8.

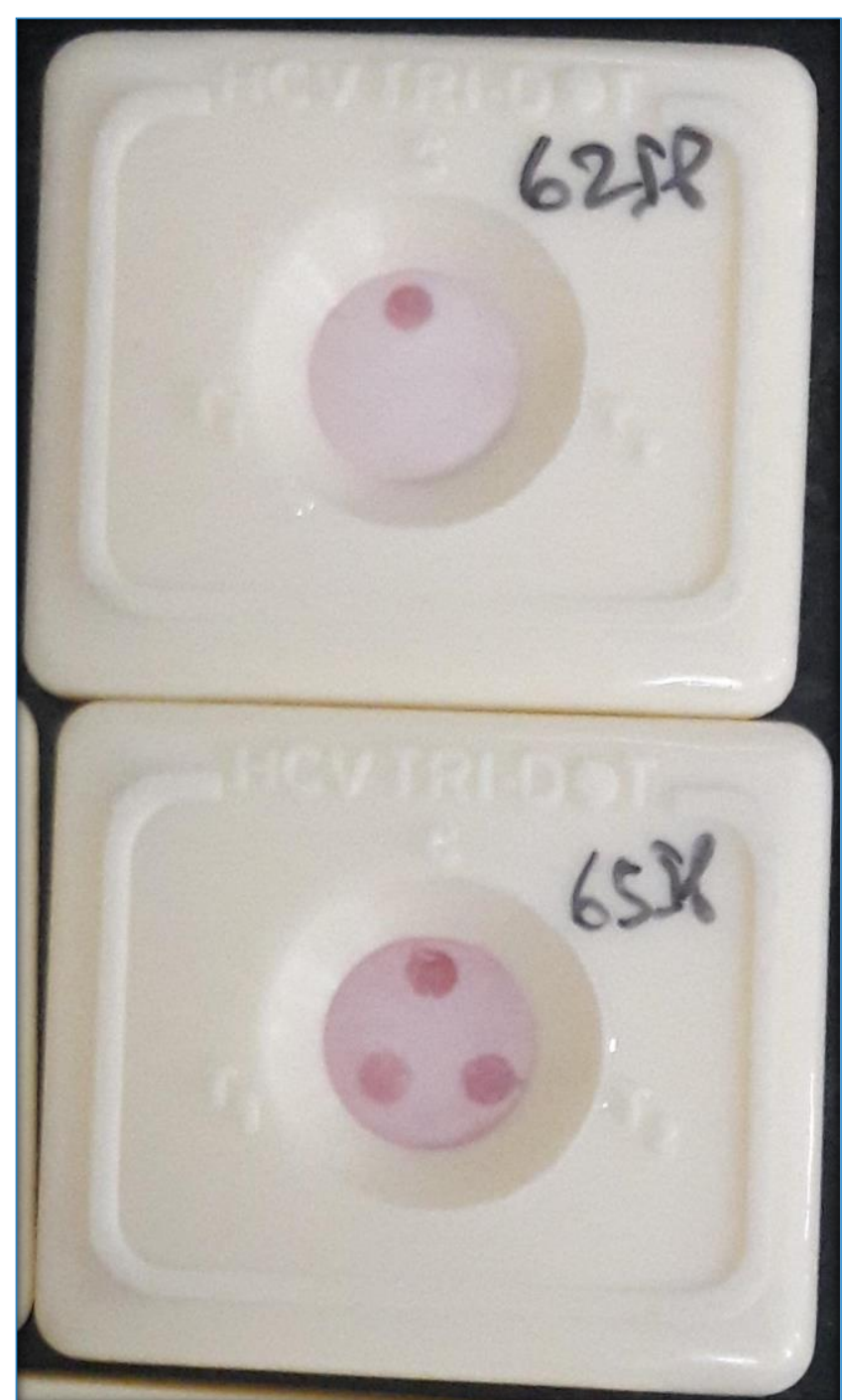

Fig-1 Shows the non-reactive (only control dot present) and reactive (both control and test dots present) results of HCV TRI-DOT test. 